\title{
Afforestation and reforestation management in Romania - migrating to sustainability and responsibility
}

\author{
Ciprian Palaghianu \\ „Stefan cel Mare” University of Suceava, Forestry Faculty, Romania \\ Corresponding author e-mail address: cpalaghianu@usv.ro (C. Palaghianu)
}

\begin{abstract}
Considering the present state of afforestation and reforestation management in Romania, the process of renewing the forestation paradigm is analysed. Most of the management systems use an iterative method of improving the outcomes. Considering the classical phases Plan-Do-Check-Adjust, the forest management system is broken into pieces in order to reveal potential gaps from planning to system adjustments regarding forestation in Romania. The official data reports, national statistics and forest regulations represent evidences of a system that fails to progress. The weak integration of PanEuropean criteria and indicators for sustainable forest management, the lack of a robust planning system and the poor capacity of accessing European funds are considered major gaps. The whole framework of afforestation and reforestation should be revised to comply with recent realities and objectives (social, economic, environmental). At present time Romanian forest management still forges tomorrow's forests using regulations fitted to communist era, without taking into account updated objectives regarding social needs, economic benefits, climate change mitigation or the new types of property. Several suggestions for improving the afforestation and reforestation framework were provided.
\end{abstract}

Keywords: afforestation, reforestation, forest management, responsibility.

\section{Introduction}

What we understand by sustainability and responsibility defines our relationship with the environment and the many resources we control. As we are increasingly confronted with environmental, social and economic issues, we need to reconsider how the community is responsibly involved in resource management activities. Facing new realities requires an adequate response from the resource managers.

Undeniable, nowadays forests mean more than timber and we all understand the importance of this multifaceted resource which provides benefits in different areas: environmental, economic, social and cultural.

Forest delivers a broad range of ecosystem services concerning climate regulation, water and soil quality, carbon sequestration, biodiversity, sociocultural and recreational values.

Many of these eco services became more visible in recent years and the society is aware of the potential costs of it (Ninan \& Inoue, 2013). Moreover, the last decade was considerable influenced by the publication of the Millennium Ecosystem Assessment (MEA, 2005) which emphasised the ecosystem services value.

In this context, afforestation and reforestation represent a form of increasing or at least preserving forest 
ecosystems benefits. For instance, afforestation, reforestation and deforestation control are considered the main types of climate change mitigation projects in the forestry sector (Reyer et al. 2009).

Considering forest as a natural resource which replenishes itself, the forest management should avoid resource depletion caused by increased wood consumption. The key is represented by sustainability which guarantees long-term availability of the forest.

Sustainability should also involve responsible management. And by being responsible we understand taking action and adjusting locally the economic, social and environmental issues and linking relevant stakeholders.

How could we define responsible forestation? Keeping in mind that forestation role, in regard to sustainability, is to ensure forest continuity or even increase forest cover, acting responsible in this direction would imply to ensure the future resource needs, securing jobs, providing recreation and wood for nearby communities, maintaining ecosystem functions or climate change mitigation role.

Swapping the socioeconomic system after 1989 was a challenging effort for Romanian forest management. The political and economic changes in Romania shaken the forest management system, causing an unpredictable pattern of transformation: legislative amendments, property fragmentation / forest cover dynamic, adjustments of technical regulations and tunings of the management systems.

Numerous scientific researches highlighted the radical changes produced in the Romanian forestry sector (Bouriaud 2005; Ioras and Abrudan 2006; Dutcă and Abrudan 2010; Palaghianu and Nichiforel 2016; Munteanu et al. 2016; Scriban et al. 2017) but fewer were focused on forestation (Palaghianu and Dutca 2017). In light of this new realities it is thought-provoking to analyse the forestation management system of Romania.

\section{Forestation management cycle}

It is common for a management system, whatever it refers to forest or not, to use an iterative method of improving its results, processes, products or services.

We will apply a classical management cycle Plan-Do-CheckAdjust for the forest management system, in order to reveal potential gaps from planning to system adjustments regarding forestation in Romania.

The Plan - it is well known that during the communism period, the plans were carefully developed and executed.

After the massive deforestations caused by the payment of war compensations to Soviet Union in timber (Banu, 2004), Romania had a determined reforestation strategy designed to reforest 1 million hectares. The project was accomplished by the year 1963, due to an impressive endeavour of reforestation (e.g. 98,400 
hectares afforested in 1953) (Negrutiu et al. 1999). This effort continued consistently afterwards, and by the year 1976 nearly 2 million ha were regenerated or forested (Law no. 2/1976).

The Law no. 2 / 1976 (National Program for the preservation and development of the forestry fund) projected forestation measures for 1976-2010. The plan was to concentrate on nurseries and plantations, with an average of approximatively 50,000 forested hectares per year (Palaghianu and Dutca, 2017). After the communism collapsed in 1989, plans for 2010 were interrupted by the political changes and the Law no. 2/1976 was abolished in 1990.

A new order, a new forestation plan and the interest in this field was resumed. One important official objective of the National Afforestation Programme (2004) and Forest Code (Law no. 46/2008), was the afforestation of 2 million hectares of degraded lands till 2035. Later, the interest in this forestation goal was reinforced by the Law no. $100 / 2010$ regarding the afforestation of degraded lands.

However, later versions of the National Afforestation Programme (2010 and 2013) have resketched the goal, turning it from 2 million hectares to 0.422 , respectively 0.229 million hectares (Palaghianu and Dutca, 2017).

These negative adjustments of a national forestation plan cannot be interpreted as robust actions towards responsibility, but additional targets were set using the European systems of funding.
The National Rural Development Program encompassed the funding of forest measures, including afforestation. The target was to forest 15 thousand hectares by SAPARD (2000-2006), nearly 50 thousand hectares by European Agricultural Fund for Rural Development (EAFRD 2007-2013) and 10 thousand hectares FEADR (2014-2020).

Do - Maybe the plan was not a solid one, but were the results and actions better?

Despite some data inconsistency between INS (National Institute of Statistics) and Romsilva (National Forestry Administration) reports, the forestation effort seems to gradually decline after 1990 (INS and Romsilva reports) to an average that ranges between 10 and 15 thousand hectares per year.

Furthermore, the forestation funding mechanisms failed to achieved their targets. The funding absorption rate for SAPARD funds (2000-2006) Measure 3.5 was $1.3 \%$ and for (EAFRD 2007-2013) Measure 221 (The first afforestation of agricultural land) was $0.08 \%$ (Palaghianu and Dutca, 2017).

Check - A simple raw evaluation is showing that results deviated far enough from the expected targets. The Romanian forestation engine seems to have gripped over the past few decades and the comparison with pre-1990 afforestation rate is not favourable to present.

Adjust - Observing the poor results, how much the afforestation and reforestation framework was adjusted in the last decades? 
The Romanian forest management is generally negatively influenced by the strict regulatory system (Nichiforel et al. 2017; Scriban et al. 2017).

Despite the overwhelming interest in regulations regarding the harvesting process and traceability of timber products, few adjustments were made regarding afforestation and reforestation management.

Nowadays, forest regeneration framework is based on the old and extremely standardized technical regulations used in the pre-1990 period (MAPM, 2000).

After we went through the whole cycle Plan-Do-Check-Adjust, we can pinpoint some potential gaps in the Romanian forestation framework.

\section{Beyond forestation regulations}

Romania has a very strict system of regulations regarding forest regeneration and afforestation. The current technical framework was republished in 2000 (MAPM, 2000), but it is essentially based on the same versions of guidelines and procedures used prior to 1990 .

The forest owners, regardless of the type of property (state or private owned forests), are forced to comply with several compulsory solutions regarding species composition or planting density, even if these have not ever been scientifically validated. These solutions and regulations were not questioned in the communist time, because they were tailored to centralised plans, but after the forest property pattern was fundamentally changed, many of the new owners did not trust the previous management system and they wanted to propose new objectives and targets for their forests.

Even though the new version of the technical regulations were published in 2000 (10 years after the fall of communism), they did not integrate new principles of forest management.

In the context of sustainable forest management (SFM) at international level there were established criteria and indicators for SFM (Pan-European criteria and indicators for sustainable forest management Lisbon, 1998; Improved Pan-European Indicators for Sustainable Forest Management, Vienna, 2003 and Madrid, 2015).

Six criteria of SFM were recognized and remained unchanged and at the 7th Ministerial Conference, held in Madrid in 2015 were endorsed two resolutions: Resolution 1: Forest sector in the centre of Green Economy and Resolution 2: Protection of forests in a changing environment.

Nevertheless, none of the six criteria were explicitly included in Romanian technical guidelines. There is a weak integration of Pan-European criteria for SFM, due to the fact that current technical guidelines were republished in 2000 and they contain minor changes from the previous versions published in 1977 and 1987.

It stands to reason that numerous changes in the forestry management system at international level have made since 1977/1987 which are not integrated in current guidelines.

Nevertheless, neither of the provisions of the EU Forest Strategy 
(EU 2013, 2015, 2018) have been integrated.

Another sensitive issue which is not addressed by the current forestation regulations is represented by the use of invasive alien species. EU has clarified the management of invasive alien species by Regulation no 1143/2014 (EU, 2014). Still, the Romanian forestation technical framework offers some forestation solutions which use invasive alien species. This issue is delicate and debatable, especially in the context of degraded lands or concerning the use of certain species (Nicolescu et al, 2018).

Moreover, the problem should be shortly clarified so that forest management does not contradict some requirements of forest certification schemes (FSC / PEFC) concerning invasive alien species.

Additional technical aspects regarding current forestation regulations were previously highlighted (Palaghianu and Dutca 2017):

- the procedures are too detailed and very restrictive (e.g. regarding species composition, density);

- current species composition solutions have not been scientifically substantiated;

- there are not emphasised new realities/targets expressing economic, social or climate-related mitigation trends.

It is obvious that Romanian forestation technical guidelines should be updated and a change was ineffectively attempted in 2016. In the recent months a new project for designing new regulations has started and we are confident that we will witness a shift towards a sustainable forest management.

Clearly, we will see some changes in several key aspects regarding afforestation and reforestation framework.

The procedure for species composition selection should be simplified using a scheme based on forest types or nominating only the main species and its minimum percentage. It is important to have a more flexible procedure because based on current species composition solutions we create the future forests, which will provide a great variety of ecosystem services for the next generations.

The tree density procedures should also be revised. It could be more efficient to establish a minimum threshold and to check tree density at stand closure not at the end of the planting activity. Furthermore, for several species tree density should decrease, according to practitioners and studies (Nicolescu et al, 2003).

It is also important for forest owners to have an increased flexibility in setting management objectives, more adequate to current realities.

\section{Conclusion}

Currently in Romania the official data reports, national statistics and forest regulations represent evidences of a system that fails to progress.

Unfortunately, forests created today in Romania, forests of the future generations will reflect the past realities of 1970-1980 type of 
management. There is a huge gap between present realities / forestry management system at international level and the outdated framework of forestation used in Romania.

The weak integration of PanEuropean criteria for sustainable forest management, the lack of a robust planning system and the poor capacity of accessing European funds are considered major gaps. The whole framework of afforestation and reforestation should be revised to comply with recent realities and objectives considering the social, economic and environmental pillars of sustainability.

The Romanian forestry system had plans to draw up, took action and had enough time to observe the effects of the current management system. Considering the adaptative management cycle Plan-Do-CheckAdjust, now it is more appropriate to be oriented towards the adjustment phase.

New realities and the significant role of forests in the environmental and social paradigm should help foster new objectives and major updates of the forestation management.

Currently Romania shapes its future forests with tools from the past. The present forestation regulations were designed for a different socioeconomic environment. The socialist settings do not match the present realities.

Adjustments were made, but mostly on forestry legal framework. An outdated management system can not be patched only by providing new sets of legal regulations. The robust approach implies the design of a brand-new technical management framework, suited for objectives regarding social needs, new property patterns, economic benefits or climate change mitigation.

\section{References}

Banu F (2004) Asalt asupra economiei Romaniei de la Solagra la SOVROM (1936-1956). Editura Nemira, Bucuresti;

Bouriaud L (2005). Causes of illegal logging in Central and Eastern Europe. Small-Scale Forestry, 4(3): 269-291;

Dutcă, I., \& Abrudan, I. V. (2010). Estimation of Forest Land Cover Change in Romania between 1990 and 2006. Bulletin of the Transilvania University of Brasov, Series II-Forestry, Wood Industry, and Agricultural Food Engineering, 52(1), 33-36.

European Commission (2013). A new EU Forest Strategy: for forests and the forestbased sector.

European Commission (2015). Multiannual Implementation Plan of the new EU Forest Strategy

European Commission (2018). Progress in the implementation of the EU Forest Strategy - A new EU Forest Strategy: for forests and the forest-based sector.

EU (2014). Regulation No 1143/2014 of the European Parliament and of the Council on the prevention and management of the introduction and spread of invasive alien species.

Ioras F \& Abrudan I V (2006) The Romanian forestry sector: privatisation facts. International Forestry Review, 8(3): 361-367;

INS (National Institute of Statistics), (2006-2016) Romanian Statistical Yearbook;

Law no. 2/1976 (1976) Legea privind adoptarea Programului national pentru conservarea si dezvoltarea fondului forestier in perioada 1976-2010 (National Program for the preservation and 
development of the forestry fund during 1976-2010);

Law no. 100/2010 (2010) Legea privind împădurirea terenurilor degradate (Law on Afforestation of Degraded Land)

MAPM (2000) Ministry of Waters, Forests and Environmental Protection - Technical regulations on composition schemes and technologies for regeneration of forests and afforestation of degraded lands, vol. 1., Bucharest

MEA (Millennium Ecosystem Assessment), 2005. Ecosystems and Human Well-being: Biodiversity Synthesis. World Resources Institute, Washington D.C.

Munteanu C, Nita M D, Abrudan I V, \& Radeloff V C (2016). Historical forest management in Romania is imposing strong legacies on contemporary forests and their management. Forest Ecology and Management, 361: 179-193;

Negrutiu F, Abrudan I V, Smith I (1999) Momente semnificative privind instalarea artificiala a padurilor pe teritoriul Romaniei, Analele Universitatii Oradea, (Fascicula Silvicultura), IV:37-46;

Nichiforel, L., Keary, K., Deuffic, P., Weiss, G., Thorsen, B. J., Winkel, G., ... \& Mifsud, E. G. (2018). How private are Europe's private forests? A comparative property rights analysis. Land Use Policy, 76, 535-552.

Nicolescu N, Petritan I, Vasilescu M, Ferreira \& Henriques S (2003). Schemele de împădurire dese şi stabilitatea monoculturilor de molid-este posibilă realizarea unui echilibru de durată. Bucovina Forestieră, 11(2): 27-35;

Nicolescu, V. N., Hernea, C., Bakti, B., Keserü, Z., Antal, B., \& Rédei, K. (2018). Black locust (Robinia pseudoacacia L.) as a multi-purpose tree species in Hungary and Romania: a review. Journal of Forestry Research, 1-15.
Ninan, K. N., \& Inoue, M. (2013). Valuing forest ecosystem services: what we know and what we don't. Ecological Economics, 93, 137-149.

Palaghianu C, Nichiforel L (2016) Between perceptions and precepts in the dialogue on Romanian forests. Bucov. For. 16(1): 3-8.

Palaghianu, C., \& Dutca, I. (2017). Afforestation and reforestation in Romania: History, current practice and future perspectives. REFORESTA,(4), 5468.

Reyer, C., Guericke, M., \& Ibisch, P. L. (2009). Climate change mitigation via afforestation, reforestation and deforestation avoidance: and what about adaptation to environmental change?. New Forests, 38(1), 15-34.

Romsilva (2012) Raport privind modul de îndeplinire a Programului de activitate al RNP-ROMSILVA (Romsilva Activity Report 2012);

Romsilva (2013) Raport privind modul de îndeplinire a Programului de activitate al RNP-ROMSILVA (Romsilva Activity Report 2013);

Romsilva (2014) Raport privind modul de îndeplinire a Programului de activitate al RNP-ROMSILVA (Romsilva Activity Report 2014);

Romsilva (2015) Raport privind modul de îndeplinire a Programului de activitate al RNP-ROMSILVA (Romsilva Activity Report 2015);

Romsilva (2016) Raport privind modul de îndeplinire a Programului de activitate al RNP-ROMSILVA (Romsilva Activity Report 2016);

Scriban R E, Nichiforel L, Bouriaud L, Barnoaiea I, Cosofret V C \& Barbu C O (2017) Governance of the forest restitution process in Romania: An application of the DPSIR model. Forest Policy and Economics. 
ISSN 2537 - 3757, ISSN-L 2537 - 3757

Proceedings of the $4^{\text {th }}$ Edition of the International Conference Integrated Management of Environmental Resources - Suceava, November 3-4 ${ }^{\text {th }}, 2017$. Editura Universității „Ștefan cel Mare” Suceava, Romania.

\section{Publisher:}

Editura Universităţii „Ştefan cel Mare” din Suceava

\section{Editors (eds.):}

Sergiu-Andrei Horodnic, Mihai-Leonard Duduman, Ciprian Palaghianu

All papers in this publication were submitted on-line and have been edited to achieve a uniform format. Authors are responsible for the content of their paper.

\section{Order to:}

„Ștefan cel Mare” University of Suceava, Forestry Faculty

Universității Street 13

720229 Suceava, Romania

Phone: +40 0230/522978 Fax: +40 0230/521664

E-mail: silvic@usv.ro

Web: http://silvic.usv.ro/imer2017/

All rights, including the right of reproduction, dissemination and translation reserved. 